\title{
PENELITIAN KEMASYARAKATAN DALAM PENJATUHAN SANKSI PIDANA BAGI ANAK DI PROPINSI BENGKULU
}

\author{
HERLITA ERYKE, S.H
}

\begin{abstract}
ABSTRAK
Di dalam proses penyelesaian perkara anak, kepentingan anak harus diutamakan dan memperoleh perlindungan khusus. Segala aktivitas aparat penegak hukum yang dilakukan dalam rangka peradilan anak harus didasarkan demi kesejahteraan anak dan kepentingan anak. Tujuan peradilan anak tidak dapat dilepaskan dari tujuan utama untuk mewujudkan kesejahteraan anak yang pada dasarnya merupakan bagian integral dan kesejahteraan sosial. Proses peradilan anak, mulai dari proses penyidikan sampai dengan penjatuhan sanksi dan penempatannya di dalam lembaga pemsyarakatan, harus mempertimbangkan laporan penelitian kemasyarakatan (Penjelasan Pasal 56 UU No 3 Tahun 1997)' Jika tidak ada Litmas maka putusan batal demi hukum.

Penelitian in bertujuan untuk mengetahui (a) ide dasar Laporan penelitian kemasyarakatan;(b)subtansi Litmas memberikan informasi tentang latar belakang dilakukannya tindak pidana anak;(c) hubungan antara Litmas dengan jenis sanksi yang dijatuhkan Hakim pada anak pelaku tindak pidana. Penelitian ini dilakukan dengan pendekatan yuridias sosiologi. Data baik data sekunder maupun primer dikumpulkan dengan cara studi pustaka, studi dokumen, dan wawancara dengan responden penelitian. Penentuan responden penelitian dilakukan dengan cara purposive. Data yang telah terkumpul dianalisa dengan kuantitatif dan kualitatif.

Penelitian menghasilkan kesimpulan:(a) ide dasar adanya Litmas merupakan suatu penaganan perkara anak yang lebih baik dan bersifat individualisasi pidana dikarenakan sebelum anak di jatuhi hukuman terlebih dahulu diteliti mengenai latar belakang kondisi sosial ekonomi serta motif dilakukannya tindak pidana anak (b) subtansi Litmas dapat mengungkapkan mengenai latar belakang tindak pidana anak karena Litmas berisi tentang : Identitas; jati diri klien, jenis pelanggaran hukum, jati diri keluarga, Data Lapangan: masalah pelanggaran hukum, latar belakang dan sebab anak melakukan tindak pidana, sikap keluarga, sikap lingkungan sosial, dampak dari permasalahan hukum. Latar belakang dan sebab pelanggaran hukum: pandangan klien dan keluarga serta lingkungan, faktor pemberat, faktor peringan. Saran dengan memperhatikan: aspek lingkungan, indivdu, sosial, keluarga. (c) Hubungan Laporan Penelitian Kemasyarakatan terhadap penjatuhan sanksi pidana bagi anak akan memberikan petunjuk bagi Hakim tentang tindakan atau hukuman apa yang seharusnya dijatuhkan terhadap anak, hubungan orang tua dengan anak, keadaan sosial ekonomi keluarga, hubungan keluarga dan anak terhadap lingkungan sekitar.Akan tetapi data tersebut tidak membawa dampak positif untuk memberikan putusan yang adil dan terbaik bagi anak, sanksi yang diberikan Hakim hanya berupa sanksi pidana penjara, dan pidana bersyarat. Saran penelitian ini adalah dalam perkara anak hendaknya ditunjang profersional aparat penegak hukum yang memahami, mempunyai dedikasi tinggi serta berminat terhadap permasalahan anak penagganan perkara anak adalah demi kesejahteraan
\end{abstract}


anak dan kepentingan terbaik anak. Dan hendaknya Penjelasan mengenai apabila putusan pengadilan yang tidak disertai dengan Litmas akan berakibat batal demi hukum dijadikan Pasal bukan dipenjelasan Pasal demi Pasal agar dasar hukumnya lebih kuat.

Kata kunci : anak nakal, tindak pidana anak, laporan penelitian kemasyarakatan

\section{A. Latar Belakang}

Anak sebagai bagian dari generasi muda yang merupakan penerus cita-cita perjuangan bangsa dan sumberdaya manusia bagi pembangunan nasional. Dalam rangka mewujudkan sumber daya manusia Indonesia yang berkualitas dan mampu memimpin serta memelihara kesatuan dan persatuan bangsa dalam wadah Negara Kesatuan Republik Indonesia berdasarkan Pancasila dan Undang-Undang Dasar 1945 di perlukan pembinaan secara terus menerus demi kelangsungan hidup, pertumbuhan dan perkembangan fisik, mental dan sosial serta perlindungan dari segala kemungkinaan yang akan membahayakan mereka dan bangsa di masa depan. Dalam upaya pembinaan dan perlindungan tersebut, dihadapkan pada permasalahan dan tantangan dalam masyarakat dan kadang di jumpai penyimpangan perilaku di kalangan anak.

Penyimpangan tingkah laku atau perbuatan melanggar hukum yang dilakukan oleh anak, disebabkan oleh berbagai faktor, antara lain adanya dampak negatif dari perkembangan pembangunan yang cepat, arus globalisasi di berbagai bidang kehidupan serta kemajuan ilmu pengetahuan dan teknologi serta perubahan gaya hidup sehingga sangat membuka kesempatan bagi anak untuk berperilaku menyimpang

Ciri, sifat dan kedudukan anak yang demikian khas membuat Penanganan perkara dengan tersangka/terdakwa anak-anak memerlukan peraturan tersendiri, untuk itu pemerintah bersama-sama dengan Dewan Perwakilan Rakyat telah mengesahkan Undang-undang No.3 Tahun 1997 tentang Pengadilan Anak, yang di muat dalam Lembaran Negara RI Tahun 1997 No.3 dan Tambahan Lembaran Negara RI No.3688, yang mulai berlaku pada Tanggal 3 Januari 1997. 
Pertimbangan utama diundangkannya UU No.3 Tahun 1997 Tentang Pengadilan Anak antara lain ialah kehendak pemerintah untuk mewujudkan suatu penanganan perkara anak yang terlibat tindak pidana secara lebih baik dan berkeperikemanusiaan dengan memperhatikan kepentingan anak, sehingga anak sebagai pelaku tindak pidana tidak di rugikan secara fisik dan mentalnya. Dengan adanya UU Pengadilan Anak tersebut diharapkan aparat penegak hukum yang menangani perkara anak, mulai dari tingkat penyidikan hingga tingkat persidangan, semuanya mendalami masalah anak, agar anak setelah perkaranya di putus secara fisik dan psikhis terjaga perkembangan jiwanya di masa depan.

Di dalam proses penyelesaian perkara anak, kepentingan anak harus di utamakan dan memperoleh perlindungan khusus. Menurut Sudarto, segala aktivitas aparat penegak hukum yang dilakukan dalam rangka peradilan anak apakah yang dilakukan oleh Polisi, Jaksa, Hakim atau Pejabat-Pejabat lainnya harus didasarkan pada suatu prinsip demi kesejahteraan anak dan kepentingan anak $^{1}$. Anak merupakan " a generation who will one day become our national leader", demikian Benjamin Fine ${ }^{2}$. Barda Nawawi Arief mengatakan tujuan dan pemikiran peradilan anak tidak dapat dilepaskan dari tujuan utama untuk mewujudkan kesejahteraan anak yang pada dasarnya merupakan bagian integral dari kesejahteraan sosial..$^{3}$

Perlindungan khusus terhadap anak pelaku tindak pidana, mulai dari proses penyidikan sampai dengan penjatuhan sanksi dan penempatannya di dalam Lembaga Pemasyarakatan, harus mempertimbangkan Laporan Penelitian Kemasyarakatan anak yang dibuat oleh Petugas Kemasyarakatan.

Laporan Penelitian Kemasyarakatan merupakan syarat mutlak dan wajib sesuai dengan Pasal 56 UU No.3 Tahun 1997 tentang Pengadilan Anak, yang berbunyi :

(1) Sebelum sidang dibuka, Hakim memerintahkan agar Pembimbing Kemasyarakatan menyampaikan Laporan

\footnotetext{
${ }^{1}$ Sudarto, Kapita Selekta Hukum Pidana, Alumni Bandung, 1996, hal 140

${ }^{2}$ Romli Atmasasmita. Problem Kenakalan Anak (Remaja), Amico, Bandung, 1985, hal 7

${ }^{3}$ Muladi dan Barda Nawawi Arief, Bunga Rampai Hukum Pidana, Alumni Bandung, 1992, hal 111
} 
Penelitian Kemasyarakatan mengenai anak yang bersangkutan.

(2) Laporan sebagaimana dalam ayat (1) berisi :

a. Data individu anak, keluarga, pendidikan, dan kehidupan sosial anak;

b. Kesimpulan atau pendapat dari Pembimbing Kemasyarakatan.

Hal senada juga terdapat dalam United Nation Standard Minimum Rules For The Administration of Juvenile Justice (The Beijing Rules) yang disahkan melalui Resolusi PBB No.04/33 Tanggal 29 November 1985 seperti dikutip Purnianti menyatakan dalam kaidah 16. Laporan-laporan pemeriksaan sosial 16.2

Pada semua perkara kecuali yang melibatkan pelanggaran-pelangaran hukum yang kecil, sebelum pihak yang berwenang secara hukum memberikan pelulusan terakhir sebelum vonis hukum dijatuhkan, latar belakang dan keadaan di mana anak itu hidup atau keadaan-keadaan dibawah mana pelangaran hukum telah dilakukan akan diselidiki secara benar sehingga mempermudah pengambilan keputusan hukum dari perkara itu oleh pihak berwenang secara hukum. ${ }^{4}$

Dalam penjelasannya dinyatakan laporan-laporan pemeriksaan sosial (laporan-laporan hukum pra vonis hukuman ) merupakan bantuan yang sangat dibutuhkan dalam kebanyakan proses-proses peradilan hukum yang melibatkan anak-anak. Pihak berwenang secara hukum akan diberitahu mengenai fakta-fakta yang relevan tentang anak itu, seperti latar belakang sosial dan keluarga, riwayat sekolah, pengalaman pendidikan dan lain-lain. Untuk tujuan ini beberapa wilayah hukum menggunakan pelayanan atau pejabat sosial khusus yang diperbantukan pada pengadilan atau dewan. Pejabat lain, termasuk pengawas-pengawas terhukum masa percobaan, juga dapat menjalani fungsi yang sama. Dengan demikian peraturan ini mengharuskan adanya petugas sosial yang memadai dan mampu menyusun laporan-laporan pemeriksaan sosial yang memenuhi syarat ${ }^{5}$.

Petugas Kemasyarakatan memegang peran penting dalam proses peradilan anak, karena Penelitian Kemasyarakatan yang dibuatnya memberikan

\footnotetext{
${ }^{4}$ Purnianti, Analisa Situiasi Sistem Peradilan Pidana Anak (Juvenile Justice System) di Indonesia, Departemen Kriminologi Fakultas Ilmu Siosial dan Politik Universitas Indonesia, Tanpa Tahun, hal 250 ${ }^{5}$ Ibid
} 
pengetahuan, petunjuk, pada Hakim tentang tindakan atau hukuman apa yang sebaiknya dijatuhkan kepada anak,sesuai dengan apa yang telah ditentukan dalam Undang-undang No 3 Tahun 1997. Dalam Laporan Penelitian Kemasyarakatan tersebut petugas LITMAS dapat memberikan saran terhadap Hakim untuk menentukan tindakan hukum apa yang paling tepat dapat dijatuhkan tehadap anak yang melakukan tindak pidana.

Tindakan hukum itu dapat berupa sanksi pidana dan/atau tindakan, sanksi pidana yang dapat dijatuhkan kepada anak delinkuen sesuai dengan Pasal 23 UU No 3 Tahun 1997 adalah pidana pokok dan pidana tambahan. Pidana pokok berupa : pidana penjara, pidana kurungan, pidana denda dan atau pidana pengawasan selain itu dapat juga dijatuhkan pidana tambahan berupa perampasan barang-barang tertentu dan atau pembayaran ganti rugi. Selain sanksi pidana terhadap anak delinkuen dapat juga dijatuhkan tindakan yang berupa :

a. Mengembalikan kepada orang tua, wali, atau orang tua asuh;

b. Menyerahkan kepada Negara untuk mengikuti pendidikan, pembinaan, dan latihan kerja; atau

c. Menyerahkan kepada Depertemen Sosial, atau Organisasi Sosial Kemasyarakatan yang bergerak dibidang pendidikan, pembinaan, dan latihan kerja.

Hakim wajib mempertimbangkan Laporan Penelitian tentang anak oleh Petugas LITMAS, bila hal ini tidak dipenuhi maka mengakibatkan putusan batal demi hukum.

Kenyataannya Hakim lebih banyak menjatuhkan sanksi pidana bukannya tindakan. Sanksi pidana yang dijatuhkan kebanyakan berupa pidana penjara. Hal ini menyimpangi saran yang diajukan oleh Petugas Kemasyarakatan dalam Laporan Penelitian Kemasyarakatan.

Laporan Penelitian Kemasyarakatan yang dibuat oleh Petugas Kemasyarakatan di Propinsi Bengkulu dari bulan Januari 2005 sampai dengan Juli 2006 jenis kejahatannya berupa : kejahatan terhadap kesusilaan, kemerdekaan, penganiayaan, pencurian/perampokan, pemerasaan, nakotika. Dalam Laporan Penelitian Kemasyarakatannya Petugas Litmas memberikan saran kepada Hakim 
untuk dapat memberikan Putusan yang seringan-ringannya pada anak tetapi kenyataannya Hakim lebih suka menjatuhkan sanksi pidana penjara bagi anak yang hukumannya berkisar antara 3 bulan sampai 1 tahun penjara ${ }^{6}$

Padahal dalam The Beijing Rules yang dirumuskan dalam Resolusi PBB No .40/33, Tanggal 29 November 1985, pada butir 19.1 : Penempatan seorang anak pada suatu lembaga merupakan upaya terakhir dari pilihan dan untuk jangka waktu yang sesingkat mungkin. Penjelasan Pasal adalah :

Ilmu Kriminologi yang progresif menyokong penggunaan perlakuan nonkelembagaan diatas perlakuan kelembagaan. Hanya terdapat sedikit atau bahkan tidak ada perbedaan dalam batas keberhasilan penempatan pada lembaga Pemasyarakatan dengan pada non-lembaga. Banyaknya pengaruh merugikan terhadap individu yang tampak tak terelakkan di dalam wadah kelembagaan manapun secara jelas tidak dapat dilebihi oleh upaya-upaya perawatan. Hal ini terutama berlaku bagi anak-anak yang rawan terhadap pengaruh-pengaruh negative. Lebih jauh, pengaruh tidaknya hanya kehilangan kebebasan tetapi juga pemisahan dari lingkungan sosialnya, pasti lebih akut bagi anak-anak ketimbang bagi orang dewasa karena tahap pertumbuhannya yang masih awal ${ }^{7}$

Penjatuhan sanksi pidana bagi anak nakal sebisa mungkin harus dihindarkan, karena sanksi pidana penjara merupakan The Last Resort yang merupakan sarana terakhir yang harus dilakukan setelah upaya-upaya lain yang bersifat pembinaan dan pencegahan tidak berhasil dilakukan.

Melihat fenomena seperti yang telah dijabarkan diatas maka penulis tertarik untuk melakukan penelitian yang berjudul:'Penelitian Kemasyarakatan

\section{Dalam Penjatuhan Sanksi Pidana Bagi Anak Di Propinsi Bengkulu”}

\section{B. Perumusan Masalah}

Berdasarkan latar belakang tersebut diatas maka dapat diangkat permasalahan sebagai berikut:

1. Apakah yang menjadi ide dasar perlunya Laporan Penelitian Kemasyarakatan terhadap penjatuhan sanksi pidana bagi anak ?

2. Apakah subtansi Laporan Penelitian Kemasyarakatan mampu memberikan informasi tentang latar belakang dilakukannya tindak pidana anak sehingga dapat digunakan bagi Hakim sebagai pertimbangan dalam penjatuhan sanksi pidana bagi anak?

\footnotetext{
${ }^{6}$ Hasil Wawancara dan Penelitian Penulis di BAPAS Tanggal 21 September 2006

${ }^{7}$ Ibid , hal 255
} 
3. Seberapa jauh hubungan antara laporan penelitian kemasyarakatan dengan jenis sanksi yang dijatuhkan Hakim pada anak pelaku tindak pidana ?

\section{Tujuan Penelitian}

a. untuk menjelaskan ide dasar perlunya laporan penelitian kemasyarakatan terhadap penjatuhan sanksi pidana bagi anak

b. untuk dapat mengetahui dan menjelasakan apakah subtansi laporan penelitian kemasyarakatan dapat memberikan informasi tentang latar belakang dilakukannya tindak pidana sehingga dapat digunakan sebagai pertimbangan hakim dalam menjatuhkan pidana bagi anak

c. untuk mengetahui hubungan antara laporan penelitian kemasyarakatan dengan jenis sanksi yang dijatuhkan hakim pada anak pelaku tindak pidana

\section{Tinjauan Pustaka}

Gejala perilaku delinkuensi anak di Indonesia, merupakan masalah aktual. Bentuk-bentuk perilaku delinkuensi anak beserta bentuk-bentuk modifikasinya cukup mengejala dikalangan usia muda. Sementara itu bentuk-bentuk perilaku delinkuensi anak yang menjurus tindak kriminal pun menunjukkan gejala yang tidak berbeda jauh ${ }^{8}$.

Di Indonesia menurut Pasal 1 angka 1 UU No Tahun 1997 tentang Pengadilan Anak, menentukan batas usia pertanggungjawaban pidana anak adalah antara 8-18 tahun dan belum menikah. Sedangkan menurut The Beijing Rules atau Standard Minimum Rules for the Administration of juvenile justice, Kaidah 4 resolusi tersebut memberikan pedoman batas usia pertanggungjawaban pidana anak, yaitu anatara 7-18 tahun, namun masih memberikan keleluasaan pada Negara-negara anggota PBB untuk mengatur sendiri sesuai dengan kondisi sosio kultural masyarakatnya, hanya diingatkan, hendaknya penetapan usia minimalnya jangan terlalu rendah

\footnotetext{
${ }^{8}$ Paulus Hadisuprapto, Disertasi "Pemberian Malu Reintegratif " Sebagai Sarana Nonpenal Penanggulangan Perilaku Delikuensi Anak (Studi Kasus Di Semarang dan Surakarta), UNDIP,2003,hal 1
} 
Adapun pengertian anak nakal atau Juvenile Deliquency dalam UU No 3 Tatun 1997 tentang Pengadilan Anak Pasal 1 angka 2 menerangkan:

Anak nakal yaitu: (a) anak yang melakukan tindak pidana atau (b) anak yang melakukan perbutan yang dinyatakan terlarang bagi anak, baik menurut peraturan perundang-undangan, maupun menurut peraturan hukum yang lain yang hidup dan berlaku dimasyarakat yang bersangkutan

Atas dasar paparan tersebut dan berdasarkan ketentuan Peraturan Perundang-undangan Pengadilan anak . maka dalam penelitian ini perilaku delikuensi anak dikonseptualisasikan, seseorang yang berumur anatar 8-18 tahun yang melakukan tindak pidana dan perbuatan yang dinyatakan terlarang bagi anak, baik menurut peraturan perundang-undangan maupun menurut peraturan hukum lain yang hidup dan berlaku dimasyarakat

Aktivitas peradilan anak yang berlandaskan pada prinsip demi kesejahteraan anak dan kepentingan anak, membawa pada pembicaraan pada asas yang melandasi campur tangan Negara lewat lembaga peradilan anak terhadap kehidupan anak dan keluarganya, yaitu asas parens patriae ${ }^{9}$. Parens patriae berasal dari bahasa latin."in loco parentis". Menurut Sudarto adalah prinsip yang menegaskan bahwa penguasa harus bertindak apabila anak-anak membutuhkan pertolongan, sedangkan anak yang melakukan kejahatan bukannya dipadana melainkan harus dilindungi dan diberi bantuan. ${ }^{10}$

Telaah historis menujukkan bahwa campur tangannya lembaga pengadilan dalam kehidupan anak dan keluarga senantiasa ditujukan untuk menaggulangi keadaan buruk yang menimpa diri anak, seperti kriminalitas anak, terlantarnya anak dan eksploitasi terhadap anak. ${ }^{11}$ Perkembangan aliran modern dalam hukum pidana yang menitik beratkan pelaku tindak pidana, dikenal adanya individualisasi dan differensiasi pemidanaan,-pemidanaan yang sesuai dengan keadaan diri pelaku tindak pidana, maka penanganan anak pelaku delinkuen lewat peradilan anak, diusahakan agar anak-anak tidak masuk dalam rumah penjara yang hanya membuat diri mereka lebih jahat dari pada sebelumnya. Segala

\footnotetext{
${ }^{9}$ Ibid, hal 134

${ }^{10}$ Sudarto,Op Cit, hal 131

${ }^{11}$ Sudarto, Op Cit hal 140
} 
aktivitas yang yang dilakukan dalam rangka peradilan anak apakah yang dilakukan oleh Polisi, Jaksa, Hakim atau Pejabat lain, harus didasarkan pada suatu prinsip demi kesejahteraan anak dan kepentingan anak. ${ }^{12}$

Berdasarkan asas "parens patriae" tersebut maka Penguasa/ Negara menyelenggarakan peradilan anak dalam rangka untuk menangulangi tindak pidana anak. Penyelenggaran peradilan anak untuk yang pertama kali diadakan pada Tahun 1899 di Illinois Amerika Serikat, dan kemudian berkembang dan tersebar sebagai dasar penyelenggaran pengadilan anak di Negara-negara bagian lain di Amerika Serikat. Asas "parens patriae” sebagai dasar penyelenggaran peradilan anak tersebut kemudian berkembang di hampir diseluruh belahan dunia $^{13}$.

Perkembangan Model- model peradilan anak yang sesuai dengan kondisi nilai sosial kultural Negara bersangkutan. Perkembangan model-model peradilan anak Model Peradilan Retributif dan Model Pembinaan Individual.

Model Peradilan retributif/pembalasan berangkat dari teori pidana dijatuhkan semata-mata karena orang telah melakukan suatu kejahatan atau tindak pidana. Pidana merupakan akibat mutlak yang harus ada sebagai suatu pembalasan kepada orang yang melakukan kejahatan. Jadi dasar pembenar dari pidana terletak pada adanya atau terjadinya kejahatan itu sendiri ${ }^{14}$

Implikasi dari Model Peradilan yang ada dan teori-teori yang melandasinya kesemuanya bertujuan untuk melindungi kepentingan terbaik anak dan untuk kesejahteraan anak, serta untuk menjatuhkan sanksi pidana terhadap anak delinkuen harus dilakukan melalui proses yang menyeluruh dan holistik.

Undang-undang Pengadilan anak menyatakan adanya keharusan membuat Laporan Penelitian Kemasyarakatan bagi anak delinkuen. Laporan Penelitian Kemasyarakatan merupakan laporan penelitian terhadap seorang tersangka/tertuduh yang menggambarkan data individualnya, keadaan rumahnya, susunan keluarganya, hubungan anak dengan orang tua/walinya, riwayat sejak lahir, riwayat sejak pelanggaran itu terjadi dan lain-lain. Sugondo menyebutnya

\footnotetext{
${ }^{12}$ Ibid, hal 140

${ }^{13}$ Paulus Hadisuprapto, Op Cit hal 135

${ }^{14}$ Muladi dan Barda Nawawi , Teori-teori dan Kebijakan Pidana , Bandung Alumni,1998,hal 10
} 
dengan "social case study" Laporan Penelitian Kemasyarakatan tersebut merupakan syarat imperative dalam penyelesaian perkara anak.

Anak yang berhadapan atau berkonflik dengan hukum (anak yang melakukan tindak pidana), wajib dibuatkan Laporan penelitian kemasyarakatan (Litmas) oleh Petugas Pembimbing Kemasyarakatan dari Balai Pemasyarakatan. Laporan Penelitian Kemasyarakatan digunakan untuk membantu Hakim, sebagai bahan pertimbangan bagi Hakim dalam memutus dan menjatuhkan sanksi bagi anak yang melakukan tindak pidana

Pada Penjelasan Umum UU No 3 Tahun 1997 tentang Pengadilan Anak, disebutkan :

Dalam penyelesaian perkara naka nakal, hakim wajib mempertimbangkan laporan hasil penelitian kemasyarakatan yang dihimpun oleh pembimbing kemasyarakatan mengenai data pribadi mapun keluarga anak yang bersangkutan. Dengan adanya hasil laporan tersebut, diharapkan hakim dapat memperoleh gambaran yang tepat untuk memberikan putusan yang seadil-adilnya bagi anak yang bersangkutan, karena dalam penjelasan umumnya lebih lanjut diuraikan : putusan Hakim akan mempengaruhi kehidupan selanjutnya dari anak yang bersangkutan, oleh sebab itu hakim harus yakin benar, bahwa putusan yang diambil akan dapat menjadi salah satu dasar yang kuat untuk mengembalikan dan mengantar anak menuju masa depan yang baik untuk mengembangkan dirinya sebagai warga yang bertanggung jawab bagi kehidupan keluarga bangsa dan Negara. ${ }^{16}$

Menggingat sangat urgensinya masalah penjatuhan sanksi pidana bagi anak yang mengharuskan adanya pembuatan Laporan Penelitian Kemasyarakatan maka penulis tertarik untuk melakukan penelitian dengan permasalahan seperti yang telah dijelaskan di halaman sebelumnya.

\section{E. Metode Penelitian}

\section{a. Pendekatan Penelitian}

Penelitian ini menggunakan metode Yuridis Sosiologis dengan mengunakan metode ini diharapkan memberikan pemahaman hukum dalam konteks social, menganalisa efektifitas hukum dalam masyarakat baik sebagai

\footnotetext{
${ }^{15}$ HR. Soegondo, Prinsip-prinsip Konsepsi Pemasyarakatan Hasil Konfrensi Lembaga 1964 Serta Pengembangannya Dewasa ini, 1994, Makalah di Sampaiakan dalam Ceramah pada SARPENAS II IKAAKIP, Lembang Bandung, Departemen Kehakimanan

${ }^{16}$ Penjelasan Umum UU No 3 Tahun 1997 tentang Pengadilan Anak
} 
sarana pengendali sosial, mengubah masyarakat dan mengatur interaksi sosial agar mencapai keadaan sosial tertentu ${ }^{17}$. Dengan menggunakan metode Yuridis Sosiologis dikarenakan bahwa hukum tidak hanya dipandang sebatas Peraturan atau kaidah-kaidah dan norma saja, namun juga meliputi bagaimana berkerjanya hukum dalam masyarakat.

\section{b. Metode Penentuan Sampel}

Populasi adalah keseluruhan obyek yang akan diteliti, dalam penelitian ini keseluruhan obyek yang akan diteliti adalah aparat penegak hukum yang terlibat dalam penyelenggaraan peradilan anak dan anak pelaku tindak pidana juga terpidana anak ${ }^{18}$. Akan tetapi tidak semua objek dapat diteliti. Penelitian ini hanya akan dilakukan pada sebagian populasi yang disebut sample. Penentuan sampel dilakukan dengan cara "purposive"19, yakni sampel ditarik dengan syarat-syarat tertentu yang harus dipenuhi sehingga unsur-unsur yang hendak diteliti telah dipenuhi sehingga data yang diperoleh benar-benar terjamin dan terpercaya ${ }^{20}$. Adapun yang menjadi sampel dalam penelitian ini sebagai berikut

a. 3 orang petugas Litmas yang bertugas masing-masing dikota bengkulu 1 orang, 1 orang petugas Litmas yang bertugas di Curup, 1 orang petugas Litmas di Manna .

b. 3 orang hakim anak yang masing-masing bertugas : Kota Bengkulu, Manna, dan Curup.

c. Pelaku tindak pidana anak maupun terpidana anak yang berada di kota Bengkulu, Manna dan Curup

1.

\footnotetext{
${ }^{17}$ Soerjono Soekanto, Pokok-Pokok Sosiologi Hukum,1988, Rajawali Press, Jakarta, hal 42

${ }^{18}$ Roni Hanitijo Soemitro, Metode Penelitian Hukum dan Jurimetri, 1990 Ghalia Indonesia, Jakarta, hal 51

${ }^{19}$ Teknik"purposive sampling” biasanya dipilih karena alasan waktu, tenaga dan biaya. Sehingga tidak dapat mengambil sampel yang besar jumlahnya dan jauh letaknya, yang ditentukan dengan berdasarkan tujuan tertentu dan harus memenuhi syarat antara lain : didasarkan pada ciri-ciri, sifat atau karakteristik tertentu yang merupakan ciri-ciri utama populasi. Subjek yang diambil sebagai sampel harus benar-benar merupakan subjek yang paling banyak mengandung ciri-ciri yang terdapat pada populasi dan penentuan karakteristik populasi dilakukan dengan teliti dalam studi pendahuluan .. Roni Hanitijo Soemitro, hal 51 ${ }^{20}$ Op.Cit . Soerjono Soekanto, hal 196
} 


\section{B. HASIL PENELITIAN DAN PEMBAHASAN}

\section{Ide Dasar Perlunya Penelitian Kemasyarakatan Dalam Penjatuhan Sanksi Pidana Bagi Anak}

Konsep ide dasar yang dipakai dalam penelitian ini adalah gagasan tentang suatu objek atau fenomena tertentu yang bersifat mendasar, yang dijadikan patokan atau sudut pandang. ${ }^{21}$ Ide dasar merupakan pandangan dunia (weltblit) yang diyakini dan menentukan cara pandang terhadap suatu fenomena. Ia berfungsi sebagai the central cognitive resource yang menentukan rasionalitas suatu fenomena, baik tentang apa yang menjadi pokok persoalan maupun cara melihat dan menjeleskan fenomena itu.

Sebagai gagasan yang bersifat mendasar, maka ide dasar lebih menyerupai cita, yakni gagasan dasar mengenai suatu hal. Misalnya cita hukum atau rechtsidee, merupakan konstruksi pikir (ide) yang mengarahkan hukum kepada cita-cita yang diinginkan. Atau seperti yang dikatakan Rudolf Stamler, cita hukum merupakan leitstern (bintang pemandu) bagi tercapainya cita-cita masyarakat. ${ }^{22}$ Karena itu, cita hukum akan mempengaruhi dan berfungsi sebagai asas umum yang mempedomani (guiding principle), norma kritik (kaidah evaluasi) dan faktor yang memotivasi dalam penyelenggaran hukum (pembentukan, penemuan, penerapan hukum) dan perilaku hukum. Jadi, dirumuskan dan dipahaminya cita hukum akan memudahkan penjabarannya ke dalam berbagi perangkat aturan kewenangan dan aturan perilaku serta memudahkan terjaganya konsistensi dalam penyelenggaran hukum ${ }^{23}$

Dalam Penyeleggaran system peradilan pidana bagi anak, Meskipun tidak pernah ditemukan dalam literature penegasan eksplisit soal gagasan dasar penelitian kemasyarakatan tetapi jika dilihat dari konsideran UU No 3 Tahun 1997 Tentang Pengadilan Anak menyebutkan :

\footnotetext{
${ }^{21}$ Dalam ajaran filsafat ajaran tentang 'ide-ide' merupakan inti dan dasar seluruh filsafat plato. Menurut Plato, ide merupakan sesuatu yang objektif dan terlepas dari subjek yang berfikir. Ide-ide tidak tergantung pada pemikiran;sebaliknya, pemikiran tergantung pad aide-ide. Pemikiran itu tidak lain daripada menaruh perhatian kepada ide-ide itu (K. Bertens, Sejarah Filsafat Yunani, 1999,Kanisius, Yogyakarta, hlm 129)

${ }^{22}$ Dikutip dari A Hamid S Attamimi, 1990, Perananan Keputusan Presiden RI Dalam Penyelenggaran

Pemerintah Negara, Disertasi pada Fakultas Pascasarjana Universitas Indonesia,Jakarta hlm 308
}

${ }^{23}$ Bernard Arief Sidharta, 1999, Refleksi Tentang Strukutur Ilmu Hukum, Mandar Maju, hlm 181 
a. Bahwa anak adalah bagian generasi muda sebagai salah satu sumber daya manusia yang merupakan potensi dan enerus cita-cita perjuangan bangsa, yang memiliki peranan startegis dan mempunyai ciri dan sifat khusus memerlukkan pembinaan dan perlindungan dalam rangka menjamin pertumbuhan dan perkembangan fisik, mental, social secara utuh, serasi, selaras, dan seimbang.

b. Bahwa untuk melaksanakan pembinaan dan memberikan perlindungan terhadap anak, diperlukan dukungan, baik yang menyangkut kelembangaan maupun perangkat hukum yang lebih mantap dan memadai, oleh karena itu ketentuan mengenai penyelenggaraan pengadilan bagi anak perlu dilakukan secara khusus.

c. ......dst

Penyelenggaraan Pengadilan Anak secara khusus itu dapat dilihat dalam

Penjelasan UU No 3 Tahun 1997 tentang Pengadilan Anak disebutkan bahwa:

"dalam penyelesian perkara anak nakal, hakim wajib mempertimbangkan laporan hasil penelitian kemasyarakatan yang dihimpun oleh Pembimbing Kemasyarakatan mengenai data pribadi maupun keluarga dari anak yang bersangkutan. Dengan adanya hasil laporan tersebut, diharapkan Hakim dapat memperoleh gambaran yang tepat untuk memberikan putusan yang seadil-adilnya bagi anak yang bersangkutan.

Putusan hakim akan mempengaruhi kehidupan selanjutnya dari anak yang bersangkutan,oleh sebab itu Hakim harus yakin benar, bahwa putusan yang diambil akan dapat menjadi salah satu dasar yang kuat untuk mengembalikan dan mengantar anak menuju masa depan yang baik untuk mengembangkan dirinya sendiri sebagai warga Negara yang bertanggung jawab bagi kehidupan keluarga, bangsa dan Negara $^{24}$.

Hal yang lebih khusus dalam menangani tindak pidana yang dilakukan anak, juga dapat dilihat dalam dalam United Nation Standard Minimum Rules For The Administration of Juvenile Justice (The Beijing Rules) yang menyebutkan pentingnya laporan penelitian kemasyarakatan. yang disahkan melalui Resolusi PBB No.04/33 Tanggal 29 November 1985 seperti dikutip Purnianti menyatakan dalam kaidah 16. Laporan-laporan pemeriksaan sosial 16.2

Pada semua perkara kecuali yang melibatkan pelanggaran-pelangaran hukum yang kecil, sebelum pihak yang berwenang secara hukum memberikan pelulusan terakhir sebelum vonis hukum dijatuhkan, latar belakang dan keadaan di mana anak itu hidup atau keadaan-keadaan dibawah mana pelangaran hukum telah

${ }^{24}$ Penjelasan UU N0 3 Tahun 1997 Tentang Pengadilan anak ,Sinar Grafika, Jakarta, Hlm 78-79 
dilakukan akan diselidiki secara benar sehingga mempermudah penagambilan keputusan hukum dari perkara itu oleh pihak berwenang secara hukum. ${ }^{25}$

Dengan demikian dapat dilihat bahwa laporan penelitian kemasyarakatan merupakan suatu cara yang ditempuh oleh Undang-Undang Pengadilan anak dalam menagani perkara anak yang berdasarkan pada treatment yang bersifat individual. Jadi anak yang akan dijatuhi pidana terlebih dahulu diteliti mengenai latar belakang tindak pidana dilakukan serta latar belakang sosial dan ekonomi serta keadaan lingkungan setempat sehinga diperoleh data yang comprehensip mengenai anak.

\section{Subtansi Laporan Penelitian Kemasyarakatan Memberikan Informasi Latar}

\section{Belakang Dilakukannya Tindak Pidana Anak}

Laporan Penelitian Kemasyarakatan untuk sidang Pengadilan Negeri dibuat khusus untuk klien anak, sebagai bahan pertimbangan bagi Hakim dalam memutus perkara anak.

Setelah pembimbing kemasyarakatan selesai melakukan penelitian kemasyarakatan hasil Litmas dikirim kepada pengadilan untuk dijadikan sebagai bahan pertimbangan Hakim dalam memutus perkara anak yang bersangkutan.

Untuk memudahkan penyusunan penelitian kemasyarakatan, dibuat formulir guna mempermudah pola pikir secara sistematis, sebab pada BAPAS terdapat bermacam-macam klien yang membutuhkan penelitian kemasyarakatan sesuai dengan keperluannya. Meskipun bermacam-macam, namun menurut Mustafa Penelitian Kemasyarakatan (LITMAS) tersebut menguraikan tentang

\section{Data Identifikasi}

a. Data ini berisi atau menyangkut data pribadi individu klien yang bersangkutan antara lain :

1. Nama Klien

2. Tempat dan tanggal lahir, jenis kelamin, pendidikan, agama, suku bangsa, pekerjaan dan status klien.

3.Ciri-ciri khusus dari klien

b. Data orang tua atau wali klien

bagi klien dewasa dengan status menikah harus diberi data mengenai isteri atau suami yang bersangkutan.

\section{Masalah}

Uraian ini berisi tentang informasi kasus atau permasalahan klien, yakni :

\footnotetext{
${ }^{25}$ Purnianti, Analisa Situiasi Sistem Peradilan Pidana Anak (Juvenile Justice System) di Indonesia, Departemen Kriminologi Fakultas Ilmu Siosial dan Politik Universitas Indonesia, Tanpa Tahun, hal 250
} 
a. Latar Belakang perbuatan termasuk faktor penyebab mengapa sampai terjadi masalah tersebut.

b. Riwayat terjadinya pelanggaran hukum yang diuraikan secara kronologis dan lengkap

c. Jika Litmas tersebut untuk sidang pengadilan negeri, supaya dicantumkan apakah klien ditahan dan sejak kapan penahanannya.

d. Uraian tentang akibat yang ditimbulkan oleh perbuatan klien tehadap :

1. Dirinya

2. Keluarganya

3. Diri korban

4. Masyarakat lingkungannya

\section{Riwayat hidup klien, meliputi :}

a. Uraian riwayat pertumbuhan klien, sejak dalam kandungan, kelahiran dan sampai saat ini

b. Perkembangan ksehatan, apakah pernah sakit yang berat yang mempengaruhi fisik dan jiwanya

c. Riwayat pendidikan formal dan nonformal yaitu pendidikan yang didapat dari keluarga dan lingkungan masyarakat

d. Riwayat pekerjaan (bagi klien yang sudah berkerja), berisi tentang pekerjaan apa, bagaimana prestasi kejanya dan tanggungjawabnya terhadap pekerjaan tersebut

e. Riwayat perkawinaan (bagi klien yang sudah nikah), yaitu tentang :

- sejarah perkawinan

- kawin atas dasar saling cinta, kawin paksa, kawin muda dan lain-lain

f. Keadaan sosial ekonomi klien, diisi khusus untuk klien yang sudah berkeluarga

\section{Pandangan masa depan}

i.bagaimana bakat, cita-citanya dan rencana masa depan

ii.inisiatif (daya prestasi dan motivasi belajar atau berkerja )

V. Tanggapan klien terhadap masalah yang dihadapinya, apakah ia menyesal, reaksi apakah yang dirasakan akibat perbuatannya itu

\section{Keadaan Keluarga}

a. riwayat perkawinaan orang tua

b. Relasi sosial dalam keluarga yaitu uraian tentang hubungan suami isteri, orang tua dengan anak, dan hubungan antara klien dengan saudara-saudaranya

c. Relasi sosial keluarga dengan lingkungan masyarakat

d. Keadaan sosial ekonomi keluarga, apakah berasal dari keluarga mampu, sedang atau kurang mampu dan pengahasilan rata-rata perbulan

e. Keadaan rumah :

1. Letak dan status rumah (rumah pribadi/rumah dinas/sewa/kontrak)

2. Penerangan (listrik/bukan)

3. Permanen, semi permanent atau darurat

\section{Keadaan Lingkungan Masyarakat}


a. menjelaskan strata kehidupan sosialnya, apakah termasuk daerah yang mendukung perkembangan pribadinya atau tidak

b. mengungkapkan asal-usul lingkungan klien berdasarkan pada apakah lingkungan TNI, pegawai negeri sipil, pedangang, pengusaha, lingkungan keagamaan dan sebagainya

VIII. Tanggapan pihak keluarga, korban, masyarakat dan pemerintah setempat. IX. Kesimpulan dan saran

a. kesimpulan

kesimpulan bukan merupakan ringkasan laporan berisi analisa dan evaluasi

b. saran

dalam memberikan saran harus memperhatinkan kepentingan klien, keluarga dan masyarakat yang dikaitkan dengan ketentuan-ketentuan perundangundangan yang berlaku

Wahyono menyatakan : Khusus penelitian untuk sidang pengadilan di Pengadilan Negeri yang menangani perkara anak, antara lain menguraikan :
a. Riwayat anak sejak lahir
b. Pergaulannya di sekolah maupun di rumah
c. Keadaan rumah tangga si anak
d. Hubungan ibu dengan bapak
e. Hubungan si anak dengan saudara-saudaranya ${ }^{26}$

\section{Hubungan antara Laporan Penelitian Kemasyarakatan dengan Jenis Sanksi yang Dijatuhkan Hakim Pada Anak}

Pengkajian diarahkan pada proses pemeriksaan oleh Hakim yang menangani kasus-kasus delinkuensi anak sehingga seorang anak dijatuhi sanksi pidana atau sanksi tindakan. Pada sisi lain, apakah dalam pemeriksaan kasuskasus delinkuensi anak tersebut khususnya anak sebagai pelaku kejahatan ada kecenderungan bagi Hakim lebih banyak menjatuhkan sanksi pidana atau lebih kearah menjatuhkan sanksi tindakan. Untuk mengetahui apakah ada kecenderungan tersebut dapat dilihat apakah praktek peradilan anak selama ini. Hakim anak lebih cenderung menjatuhkan sanksi pidana atau tindakan yang dihubungkan Laporan Penelitian Kemasyarakatan yang dibuat oleh Petugas Pembimbing Kemasyarakatan.

Berdasarkan penelitian yang penulis lakukan di Pengadilan Negeri di Propinsi Bengkulu wawancara dengan Hakim Sujipto, Parulian dan

\footnotetext{
${ }^{26}$ Wahyono dan Siti Rahayu, Tinjauan Tentang Peradilan Anak di Indonesia,1993, Sinar Grafika, Jakarta, hlm 73
} 
Masridawati ${ }^{27}$ di peroleh informasi bahwa Hakim mempertimbangkan Laporan Penelitian Kemasyarakatan yang dibuat oleh Pembimbing Kemasyarakatan dalam proses penyelesaian perkara anak. Menurut informan yang diwawancari bahwa dalam penyelesaian perkara anak, "Hakim selalu mempertimbangkan kesimpulan atau saran dari pembimbing kemasyarakatan dalam menjatuhkan sanksi/pidana bagi anak banyak faktor lain diperhatikan oleh Hakim, Litmas merupakan syarat yang mutlak ada jadi harus diperhatikan" demikan Parulian Mengatakan. Akan tetapi jika dilihat dalam putusan yang dibuat Hakim Laporan penelitian kemasyarakatan hanya merupakan syarat formal bagi Hakim dalam memenuhi ketentuan undang-undang pengadilan anak, karena didalam putusan hanya disebutkan dengan mempertimbangkan Litmas yang dibuat pembimbing kemasyarakatan terlampir dalam putusan...........dst, jelas tidak mengambarkan bahwa putusan Hakim mempergunakan Litmas. Litmas hanya digunakan sebagai pelengkap putusan tanpa dilihat subtansi dari Litmas tersebut.

Sedangkan dalam penyelesian perkara anak, Penelitian Kemasyarakatan yang dibuat oleh Pembimbing Kemasyarakatan merupakan salah satu pedoman yang wajib dipertimbangkan oleh Hakim dalam menentukan hukuman yang dijatuhkan pada anak tersebut. Namun Hakim dapat saja berpendapat lain karena Hakim independent dalam memberikan putusan, dengan kata lain hakim tidak terkait dalam arti tidak ada keharusan untuk mengikuti kesimpulan dari penelitian kemasyarakatan. Secara yuridis formal bahwa rekomendasi Pembimbing Kemasyarakatan anak yang tertuang dalam Laporan Penelitian Kemasyarakatan, hanya menjadi salah satu pertimbangan bagi Hakim dalam menentukan putusan yang terbaik bagi masa depan anak yang melanggar hukum

Berdasarkan putusan tersebut dapat ditarik kesimpulan bahwa Hakim mengunakan saran Litmas hanya untuk memenuhi ketentuan secara formal didalam putusan perkara anak. Dikarenakan Litmas yang dilihat hanya bagian saran saja sedangkan uraian-uraian yang menjadi pokok subtansi Litmas tidak disebutkan di dalam putusan Hakim. Dari hasil wawancara Peneliti dengan Hakim anak yang diangkat berdasarkan SK Mahkamah Agung itu bahwa dalam

\footnotetext{
${ }^{27}$ Hasil wawancara penulis dengan Hakim anak di Propinsi Bengkulu
} 
menjatuhkan sanksi terhadap anak. Hakim mempertimbangkan banya aspek berupa fakta-fakta yang terungkap di persidangan, alasan pemberat maupun peringan pidana, apakah anak termasuk resedivis atau bukan dan apakah tindak pidana yang dilakukan anak tersebut mendapat perhatian besar dari masyarakat/mengkhwatirkan masyarakat.

\section{PENUTUP}

\section{Kesimpulan}

1. Ide dasar Laporan peneitian kemasyarakatan merupakan suatu penaganan perkara anak yang lebih baik bersifat individualisasi pidana merupakan ciri dari aliran modern yang menganut paham keseimbangan antara unsur tindak pidana (objektif) dan pelaku (subjektif) serta juga menganut paham The Treatment Individual Sanction di karenakan sebelum anak dijatuhi hukuman terlebih dahulu di teliti mengenai latar belakang tindak pidana dilakukan serta latar belakang social dan ekonomi serta keadaan lingkungan anak.

2. Subtansi Laporan Penelitian Kemasyarakatan dapat mengungkapkan mengenai latar belakang tindak pidana anak karena di dalam Laporan Penelitian Kemasyarakatan berisi data mengenai:

- Identitias

Jati diri klien

Jenis Pelanggaran Hukum

Jati diri keluarga

- Data Lapangan

Masalah pelanggaran hukum

Latar belakang dan sebab anak melakukan tindak pidana

Sikap keluarga

Sikap Lingkungan Sosial

Dampak dari permasalahan hukum

- Latar belakang dan sebab masalah pelanggaran hukum

- Pandangan klien dan keluarga serta lingkungan 
Faktor pemberat

Faktor peringan

- Saran dengan memperhatikan:

Aspek Lingkungan

Aspek Individu

Aspek sosial

Aspek keluarga

3. Hubungan Laporan Penelitian Kemasyarakatan terhadap penjatuhan sanksi pidana bagi anak bahwa hasil Penelitian Kemasyarakatan akan memberikan petunjuk bagi Hakim tentang tindakan atau hukuman apa yang seharusnya dijatuhkan terhadap anak dengan memperhatikan kenakalan anak, hubungan orang tua dengan anak, keadaan sosial ekonomi keluarga, hubungan keluarga dan anak terhadap lingkungan sekitar. Akan tetapi data tersebut tidak membawa dampak positif untuk memberikan putusan yang adil dan terbaik bagi anak, sanksi yang diberikan Hakim hanya berupa sanksi pidana penjara, dan pidana bersyarat.

\section{Saran-saran}

1. Di dalam proses penyelesian perkara anak hendaknya ditunjang dengan profersional aparat penugak hukum yang memahami, mempunyai dedikasi tinggi serta berminat terhadap permasalahan anak sehingga putusan yang dijatuhkan terhadap anak adalah demi kesejahteraan anak dan kepentingan terbaik anak.

2. Hendaknya Penjelasan mengenai apabila putusan pengadilan mengenai tindak pidana anak yang tidak disertai dengan Laporan Penelitian Kemasyarakatan akan berakibat batal demi hukum dijadikan Pasal bukan ditempatkan pada penjelasan Pasal demi Pasal agar dasar hukumnya lebih kuat. 


\section{DAFTAR PUSTAKA}

Arief Sidharta, Bernard, 1999, Refleksi Tentang Struktur Ilmu Hukum, Bandung, Mandar maju

Atmasasmita, Romli, 1985, Problem Kenakalan Anak- anak Remaja (Yuridis, Sosio, Krimonologi), Bandung, Armico.

--------------, 2005, Teori dan Kapita Selekta Kriminologi, Bandung, Reflika Aditama

------------, 1996, Sistem Peradilan Pidana (Criminal Justice System), Bandung, BinaCipta.

Attamimi, A Hamid, Peranan Keputusan Presiden RI Dalam Penyelenggaraan Pemerintah Negara, Disertasi, Jakarta, Pascasarjana Fakultas Universitas Indonesia.

Ashshofa, Burhan, 2004, Metode Penelitian Hukum, Jakarta, Rineka Cipta

Bertens, K, 1999, Sejarah Filsafat Yunani, Yogyakarta, Kanisius

Costin, B Lela, 1972,Child Welfere, Policies and Practise,: The Child and The Court, New York, MrGrawHillBook Company

Dellyana, Shanty, 1998, Wanita dan Anak Di Mata Hukum, Yogyakarta, Liberty

Eka Putra, Hendra, 2002, Masalah Pembinaan dan Upaya Pembinaan Anak Binaan Dalam Perlindungan Anak dan Remaja Di Kota Bengkulu, Skripsi, Fakultas Hukum UNIB.

Elizabeth B Hurlock, Terjemahan Istiwidayati \& Sudjarwo, Psikologi Perkembangan, Jakarta, Erlangga.

Glueck Sheldon, 1950, Unreveling Juvenile Delinquency, Massachusetts, Havard University

Hadisuprapto, Paulus, 2003, "Pemberian Malu Reintegratif Sebagai Sarana Nonpenal Penanggulangan Perilaku Delikuensi Anak (Studi Kasus di Semarang dan Surakarta), Disertasi, Magister Ilmu Hukum UNDIP

-----------,1997,Juvenille Delinquency, Pemahaman dan Penanggulangannya, Bandung, Citra Aditya Bandung.

Herlina, 2003, Bantuan Hukum Kepada Pelaku Tindak Pidana dalam Kaitannya dengan Peran BAPAS, Jakarta 
Hirschi, Travis, 1969, Causes Of Delinquency, Berkley, The University Of The California

Huda, Chairul, 2006, Dari Tiada Pidana Tanpa Kesalahan Menuju Kepada Tiada Pertanggungjawaban Pidana Tanpa Kesalahan, Jakarta, Prenada Media.

Kartono, Kartini, 2005, Patologi Sosial II (Kenakalan Remaja), Jakarta, Rajawali Press.

Lopa, Baharuddin, 1997, Permasalahan Pembinaan dan Penegakan Hukum Di Indonesia, Bulan Bintang.

Merton Nisbet, K Robert, 1976, Contempory Social Problems, Chicago, Harcourt Brace Juvanovich.

Muladi, Kapita Selekta Sistem Peradilan Pidana, Semarang, Badan Penerbit Universitas Diponegoro.

, 1992, Teori-teori dan Kebijakan Pidana, Bandung, Alumni.

--------------, 1992, Bunga Rampai Hukum Pidana, Bandung, Alumni Bandung

Nawawi Arief, Barda, 1994, Kebijakan Legislatif dalam Penanggulangan Kejahatan dengan Pidana Penjara, Semarang, Badan Penerbit Universitas Diponegoro.

--------, 2007, Proses Dua Fase (Twee-Fasen Proces) , Catatan Kuliah , 2005, Beberapa Aspek Kebijakan Penegakan dan Pengembangan Hukum Pidana, Bandung, Citra Adtya Bandung.

Persada. ,2002, Sari Kuliah Perbandingan Hukum Pidana, Jakarta, RajaGrafindo , 1997, Bunga Rampai Kebijakan Hukum Pidana, Jakarta, Citra Aditya Bandung.

Rahayu, Siti, 1982, Psikologi Perkembangan, Yogyakarta, Yogyakarta University Press.

Rahayu, Siti dan Wahyono, 1993, Tinjauan Tentang Peradilan Anak Di Indonesia, Jakarta, Sinar Grafika.

Sholehuddin, 2004, Sistem Sanksi Dalam Hukum Pidana (Ide Dasar Double Track System \& Implementasinya), Jakarta, RajaGrafindo

Sudarto, 1996, Kapita Selekta Hukum Pidana, Bandung, Alumni Bandung.

Sumarsono, 1997, Diktat Departemen Teknis Kemasyarakatan Bidang Pembinaan, Bandung 
Sitepu, Sudirman, 2005, Model Pembinaan Bagi Anak Yang Melakukan Tindak Pidana Dalam Prespektif UU. NO 23 Tahun 2002 Tentang Perlindungan Anak Di Propinsi Bengkulu, Bengkulu, PHKA2

Simanjuntak, B. 1997, Latar Belakang Kenakalan Remaja, Bandung, Alumni Bandung.

Singgih Gunarso, 1989, Perubahan Sosial dalam Masyarakat, Jakarta, PAU FIS UI. Soegondo, HR, 1994, Prinsip-prinsip Konsepsi Pemasyarakatan Hasil Konfrensi

Lembaga Serta Pengembangannya Dewasa ini, Bandung, Departemen Kehakiman.

Soekanto, Soerjono, 1990,Pengantar Penelitian Hukum, Jakarta, UI PRESS.

Soemitro, Roni Hanitijo, 1990, Metode Penelitian Hukum dan Jurimetri, Jakarta, Ghali Indonesia.

Soekamto, Soerjono, 1983, Faktor-Faktor yang Mempengaruhi Penegakan Hukum, Jakarta, Sinar Grafika.

Soetodjo, Wagianti, 2006, Hukum Pidana Anak, Bandung, Reflika Aditama.

Soewandi, Mirianti,1990, Pembinaan Pelanggar Hukum Di Luar LAPAS, Jakarta

-----------, 1990, Peranan Bapas dalam Perkara Anak, Jakarta.

Suyanto, Bagong, 2005, Metode Penelitian Sosial Berbagai Alternatif Pendekatan, Jakarta, Prenada Media.

Sudarsono, 2004, Kenakalan Remaja, Jakarta, Rieneka Cipta

Purnianti, tanpa tahun, Analisis Situasi Sistem Peradilan Pidana Anak (Juvenille Justice System) di Indonesia, Departemen Kriminologi, Fakultas Ilmu Sosial dan Ilmu Politik Universitas Indonesia, didukung Oleh UNICEF Indonesia

Widiowati, 1983, Anak dan Wanita dalam Hukum, Jakarta, LP3ES

Jurnal Hukum, Edisi Nopember 2005, Law Reform Pembaharuan Hukum, Program Magister Ilmu Hukum Pascasarjana Diponegoro Semarang.

\section{Peraturan Perundang-undangan}

Undang-undang N0.4 Tahun 1979 tentang Kesejahteraan Anak

Undang-undang N0.12 Tahun 1995 tentang Pemasyarakatan 
Undang-undang N0.3 Tahun 1997 tentang Pengadilan Anak

Resolusi Majelis Umum PBB N0. 40/33 tanggal 19 Nopember 1985 tentang PeraturanPeraturan Minimum Standar Perserikatan Bangsa-bangsa Mengenai Administrasi Peradilan Bagi Anak. (The Beijing Rules)

Resolusi Majelis Umum PBB N0. 45/112 tanggal 14 Desember 1990 tentang Pedoman Perserikatan Bangsa-bangsa Dalam Rangka Tindak Pidana Anak (Riyadh Guiddelines)

Rancangan Undang-Undang Hukum Pidana Nasional Tahun 2005 